\title{
Study on Individual PAHs Content in Ultrafine Particles from Solid Fractions of Diesel and Biodiesel Exhaust Fumes
}

\author{
Małgorzata Szewczyńska, Małgorzata Pośniak, and Elżbieta Dobrzyńska \\ Central Institute for Labour Protection, National Research Institute, Czerniakowska 16, 00-701 Warsaw, Poland \\ Correspondence should be addressed to Małgorzata Szewczyńska; mapol@ciop.pl
}

Received 5 June 2012; Revised 30 July 2012; Accepted 4 August 2012

Academic Editor: Jean-Luc Blin

Copyright (C) 2013 Małgorzata Szewczyńska et al. This is an open access article distributed under the Creative Commons Attribution License, which permits unrestricted use, distribution, and reproduction in any medium, provided the original work is properly cited.

\begin{abstract}
In order to characterize PAHs emissions of diesel engine fuelled with diesel and its blend (B20, B40). In the particle phase, PAHs in engine exhausts were collected by fiberglass filters using Electrical Low Pressure Impactor (ELPI) and then determined by a high performance liquid chromatography with a fluorimetric detector (HPLC-FL). The main content in exhaust gases from diesel engine, regardless the type of applied fuel, is constituted by the particles fraction of diameter $<0.25 \mu \mathrm{m}$. Particles sized $<0.25 \mu \mathrm{m}$ constituted on average approximately $68 \%$ of particles in diesel exhaust gases and approx. $50 \%$ of particles emitted by biodiesel $\mathrm{B} 20$ and $\mathrm{B} 40$. When the B100 bioester additive was applied, the total emission of particles was reduced thus the volume of toxic substances adsorbed on them was lower. The analysis of chemical composition of $<0.25 \mu \mathrm{m}$ exhaust gas fraction showed that there were mainly 3- and 4-ring aromatic hydrocarbons in the exhaust gas of diesel fuel while in B40 single PAHs with the number of rings of 4 and 5 were detected. An application of ELPI permitted a further separation of $<0.25 \mu \mathrm{m}$ particle's fraction and a real-time determination of interalia number, mass, and surface concentrations.
\end{abstract}

\section{Introduction}

In an atmospheric air and in the air surrounding people in work and life premises, there are particles which may have a negative impact on human health. One of the most important sources of factors dangerous to health are diesel engine exhaust fumes, that is, mixtures of chemical compounds created as a result of incomplete combustion of diesel fuel and engine oil, as well as modifiers and contaminants contained in them. These undesired combustion products are emitted to the atmosphere in the form of particulates of various sizes and shapes, and in the form of gases and vapours.

Diesel engine exhaust emissions are of a major interest to researchers at national and international levels as demonstrated both by numerous publications resulting from analyses of gas and particular phase, evaluations of occupational and environmental exposure, and toxicological and epidemiological studies, and by reviewing publications indicating directions for further research in the area [1-3]. The publications are concerned mainly on exhaust gases emitted during combustion of conventional fuels. With reference to the necessity to reduce the emission of contaminations from internal-combustion engines, the growing worldwide interest regarding the application of environment-friendly fuels is observed. In many countries, studies are conducted with a view to replace a conventional fuel (petrodiesel) with alternative fuels, such as biodiesel and ethanol [4-6]. At the same time a question arises whether alternative fuels bring about benefits only or may also induce unfavourable effects on environment and human health, similar to the effects caused by multicompound mixtures of harmful xenobiotics created as a result of combustion of conventional fuels (e.g., carcinogenic, mutagenic and fertility impairing ones), emitted to the environment both in a gas phase and in the form of fine and ultrafine particles [7-9].

However, the literature data indicates that particulate matter (PM) is currently the most serious air contaminant causing nearly 300,000 deaths every year in Europe. Epidemiological examinations indicate that the growth of PM concentrations leads to diseases of respiratory and cardiovascular system and even to deaths $[10,11]$. Fine PM particles $(\mathrm{dp}<$ $2.5 \mu \mathrm{m})$ cause pneumonia and systemic health effects [12]. 
Contrary to the behaviour of inhaled PM10 and PM2.5, ultrafine particles deposited in lungs have the ability to penetrate tissue and undergo interstitialization as well as to be absorbed directly into the bloodstream. Therefore, they are not easily removed from the body and may have immediate effect. An exposure to ultafine particles, even if components are not very toxic, may cause oxidative stress, inflammatory mediator release, and induce lung disease and other systemic effects $[13,14]$. Moreover, conducted studies [15] indicate that employees exposed to this type of PM suffer fairly more often from neoplastic diseases. The carcinogenic process under the influence of PM, and especially ultrafine fractions ( $\mathrm{dp}<2.5 \mu \mathrm{m})$ containing mixtures of xenobiotics, has not been fully investigated yet.

Studies published up to now concerning exhaust fumes originating from biofuels do not strictly confirm the reduction of harmful xenobiotics emission in comparison with conventional fuel [16-21]. Diverse point of views on emission of particles originating from petro- and biodiesel fuel are presented in the literature, especially on forming of fine particles, including nanoparticles $[22,23]$. Some scientists claim that PM emission of particles from biodiesel increases compared to conventional fuel while others observe only slight changes. One study indicates that adding $20 \%$ of biofuel to conventional fuel in diesel engines induced a reduction of PM emission by $16-33 \%$, carbon dioxide by $11-25 \%$, and hydrocarbons by 19-32\% in total. [24] Studies of Westphal et al. [25] show that the use of cold-pressed rapeseed oil as a fuel results in an increased emission of mutagenic compounds compared to the reference diesel fuel. However, the studies carried out up to now are insufficient to draw unequivocal conclusions.

Harmful effects caused by the particulates matter, are chemical composition dependant. The published data suggests that, due to the adsorption or condensation phenomena, significant amounts of gases or volatile organic substances may sediment on solid particles and in such combinations may penetrate respiratory tracts of workers. Toxic effects of dusts depend on diameter of comprising particles. The ability of fine particles (of diameters (dp) smaller than $2.5 \mu \mathrm{m}$ ) to penetrate lung airways and gas-exchange regions results in considerably higher bioavailability of enclosed chemical substances than the bioavailability of substances present in larger particles. However, recognition of a toxic activity of very fine dust fractions (smaller than $2.5 \mu \mathrm{m}$ ) is so far incomplete.

Polycyclic aromatic hydrocarbons (PAHs) are widespread contaminants which can be deposited onto particles formed during an incomplete combustion of organic matter in the presence of air. Since several PAHs and some of their degradation products (oxygenated and nitrated PAHs) are known to have high carcinogenic and mutagenic potential [26], they have been consequently included in the European Union priority lists of pollutants $[27,28]$. Benzo(a)pyrene (a 5-ring $\mathrm{PAH}$ ), considered one of the most carcinogenic PAHs, has been used as an indicator of environmental PAH exposures.
The review of the topic literature points to the existing gaps in research on composition of ultrafine particles originating from combustion of both types of fuel.

Therefore, this paper focuses on the use of low-pressure cascade impactor (Electrical Low Pressure Impactor ELPI) for the separation of individual fractions of fine particles of diesel exhaust gases resulting from a combustion of biofuels and aims to investigate the content of polycyclic aromatic hydrocarbons (PAHs).

\section{Materials and Methods}

2.1. Chemicals and Materials. A standard PAHs mixture and corresponding individual compounds were obtained from Supelco. The standard PAHs mixture (EPA 610 Polynuclear Aromatic Hydrocarbons Mix 100-2000 $\mathrm{g} \mathrm{mL}^{-1} \mathrm{MEOH}$ : $\mathrm{CH}_{2} \mathrm{Cl}_{2}(1: 1)$ ) contains: naphthalene (NA), acenaphtene $(\mathrm{AC})$, fluorene $(\mathrm{FL})$, phenanthrene $(\mathrm{PH})$, anthracene $(\mathrm{AN})$, fluoranthene (FLR), pyrene (PY), benzo(a)anthracene $(\mathrm{B} a \mathrm{~A})$ : chrysene $(\mathrm{CH})$, benzo $(b)$ fluoranthene $(\mathrm{B} b \mathrm{~F})$, benzo $(k)$ fluoranthene $(\mathrm{B} k \mathrm{~F})$, dibenzo( $a h)$ anthracene (DBA) and benzo $(a)$ pyrene $(\mathrm{BaP})$, benzo(ghi)perylene $(\mathrm{B} g h i \mathrm{P})$, and indeno(1,2,3-cd)pyrene (IN).

Acetonitrile, dichloromethane, and methanol were of analytical grade and were purchased from Sigma-Aldrich. Iso-propanol was purchased from J. T. Baker (Deventer, Netherlands). Milli-Q water, obtained with a Milli-Q system (Millipore, Bedford, MA, USA), was used for analysis. SigmaAldrich SPE 12 vacuum system (Visiprep SPE Vacuum Manifold) was used for extraction. Bakerbond PolarPlus columns were purchased at J. T. Baker (Deventer, The Netherlands).

2.2. Sampling Site. The test stand used for generation and studies of diesel and biodiesel exhausts was prepared in a garage of ca. $5 \times 4 \mathrm{~m}$ in size. For the presented studies, a diesel common rail engine system (from the car Skoda Fabia) of $2.0 \mathrm{~L}$ volumetric capacity with $130 \mathrm{~kW}$ of power at $1,400 \mathrm{rpm}$ manufactured in 2007 was used. The engine was mounted on a portable trolley (Figure 1). A commercial EKODIESEL PLUS 50 (by Polish Oil Concern ORLEN, Poland) of cetane number not smaller than 51 , density of $820-845 \mathrm{~g} \mathrm{~m}^{-3}$ and the sulphur content not higher than $50 \mathrm{mg} \mathrm{kg}^{-1}$ was used as a diesel fuel and a commercial Bioester 100 (by Refinery Trzebinia, Group ORLEN, Poland) was a biofuel derived from plant oils. Three types of fuel were preparthed in laboratory and used in this study: ON (100\% diesel), B20 (20\% bioester B100, and $80 \%$ ON), B40 (40\% bioester B $100+60 \%$ ON). Fuel and biofuel properties are given in Table 1.

2.3. PAHs Sampling and Analysis. PAHs samples of particlephase were collected by using a PAHs sampling system ELPI (Dekati, Finland) at a temperature below $52^{\circ} \mathrm{C}$ for 7 days for 5-6 hours at the flow rate of $30 \mathrm{~L} \mathrm{~min}^{-1}$. About 9,000-10,800 L of air was passed through the ELPI sampler every day.

Basic parameters of ELPI operations are presented below.

impactor output pressure: $100 \mathrm{~m}$ bar, impactor input pressure: $1013 \mathrm{~m}$ bar, 


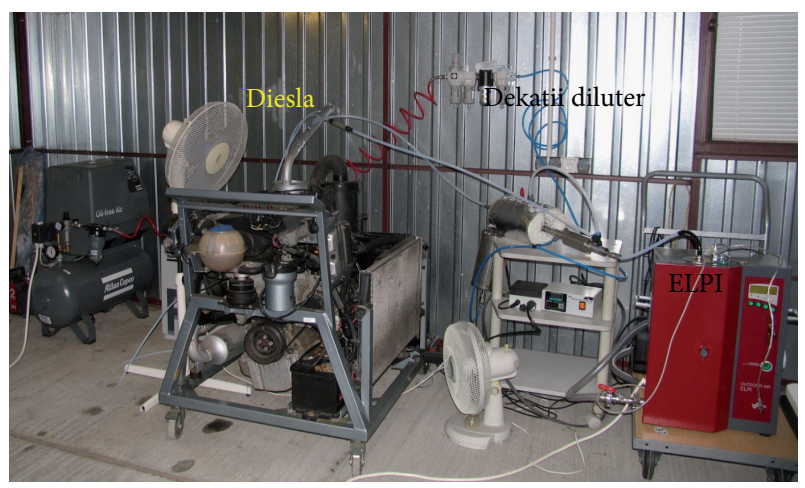

Figure 1: The test stand for generation and examination of diesel engine exhausts.

TABLE 1: Fuel and biofuel properties.

\begin{tabular}{ll}
\hline & Fuel \\
\hline Appearance & Yellow liquid \\
Boiling point & $347^{\circ} \mathrm{C}$ \\
The temperature of freezing & $0 \div-300^{\circ} \mathrm{C}$ \\
Flash point & Not less than $120^{\circ} \mathrm{C}$ \\
Ignition temperature & Under $250^{\circ} \mathrm{C}$ \\
Limit of explosiveness & The product does not pose a risk \\
of explosion \\
Vapour pressure in temp. & $50^{\circ} \mathrm{C}:<1 \mathrm{kPa}$ \\
Density (6) & $0.860 \div 0.900 \mathrm{~g} \mathrm{~cm}{ }^{-3}$ \\
Kinetic viscosity (20) & $3.5-5 \mathrm{~mm} \mathrm{~s}^{-1}$ \\
Solubility & Insoluble in water; soluble in \\
Heat of combustion & most organic solvents \\
\hline & ca. $40190 \mathrm{~kJ} / \mathrm{kg}$ \\
\hline Fatty acid (Rapeseed) Methyl & Biofuel \\
Esters (RME) content & $96.5 \%(\mathrm{by} \mathrm{mass})$ \\
Density at $15^{\circ} \mathrm{C}$ & max. $900 \mathrm{~kg} / \mathrm{m}^{3}$ \\
Viscosity at $40^{\circ} \mathrm{C}$ & max $5.00 \mathrm{~mm} / \mathrm{s}$ \\
Flash point & $101^{\circ} \mathrm{C}$ \\
Cetane number & 51.0 \\
Specific energy & $37.7 \mathrm{MJ} / \mathrm{kg}$ \\
\hline
\end{tabular}

flow: $30 \mathrm{~L} \mathrm{~min}^{-1}$,
charging voltage (U): $5 \mathrm{kV}$,
charging current (I): $1 \mu \mathrm{A}$,
correlation coefficient: enabled,
type of particle diameter: aerodynamic.

Sampled gas was drawn from the tailpipe and diluted in an ejection double dilutor (Dekati, Finland) enabling to control the dilution ratio around 64. The engine was lunched $15 \mathrm{~min}$ before collecting particle-phase PAHs with fuel corresponding to the cycle of measurements. Particlephase PAHs were collected on fiberglass filters weighed on an analytical electronic balance (Mettler Toledo AT261, Switzerland) before and after each collection. Before each weighting the filters were preconditioned in a desiccator for $10 \mathrm{~h}$ to remove moisture. The samples were stored in a refrigerator at $4^{\circ} \mathrm{C}$ for less than 7 days until extraction.

PAHs were extracted from filters with $10 \mathrm{~mL}$ dichloromethane. A sonic bath was also used with closed vials for $30 \mathrm{~min}$ in ice to prevent losses by volatilization. SPE method with a BakerBond PolarPlus column and a mixture of acetonitrile/isopropanol $(1: 1, \mathrm{v}: \mathrm{v})$ was applied in order to clean samples before further HPLC analysis.

Separation and identification of the PAHs were achieved by using HPLC (EliteLaChrom, Merck Hitachi) with fluorescence detection (FL) in accordance with methods described in the standard PN-Z-04240-5 2006. [29] A reversed phase HPLC column (Pinnacle II PAH, $150 \times 32 \mathrm{~mm}, 5 \mu \mathrm{m}$ particle size) by Restek was used with a pre-column $(20 \times 3.2 \mathrm{~mm})$. The flow rate was $0.97 \mathrm{~mL} \mathrm{~min}^{-1}$ and the injection volume was $10 \mu \mathrm{L}$. Elution was performed with a gradient starting from an eluent composition of $50 \%$ acetonitrile in water (up to $5 \mathrm{~min}$ ). The acetonitrile concentration was increased up to $100 \%$ in $25 \mathrm{~min}$ and maintained at $100 \%$ for $5 \mathrm{~min}$. The wavelength of the fluorescence detector was altered for each PAHs [30]. The data was collected and processed with HP ChemStation software. LOD results for selected PAHs, determined based on blank analysis, did not exceed $0.1 \mathrm{ng} \mathrm{m}^{-3}$.

\section{Results and Discussion}

Concentrations and Size Distributions of Particles Emitted from Diesel Engine Exhaust Fumes. A subject to observation during real-time measurements was a distribution of particles for respective fractions emitted from diesel engine operating with the use of various biofuel mixtures for 2 to 5 hours on average. During real-time measurements with the use of ELPI the data was collected concerning changes in composition of fractions. The data was registered each 10 seconds. After ceasing the engine operations, the data was computed and processed with the use of ELPIVI 4.0 software and then, thanks to ELPIxls tab, transferred to Excel and saved in the form of calculation worksheets and charts.

Examples of histograms of particle distribution obtained during one measurement day for $\mathrm{ON}$ and B40 fuels are presented in Figure 2.

An analysis of an exemplary data presented in Figure 2 for number concentration distribution over one measurement day confirms a particle emission reduction obtained for B40 by $70 \%$ when compared to $\mathrm{ON}$.

Similarly, when examining mean values of number, diameter and mass concentration distribution, a reduction of total particle emission is observed, respectively, by $54 \%$ (B20) and 78\% (B40), 32\% (B20) and 88\% (B40), and 47\% (B20) and 69\% (B40) compared to the values obtained for ON (Figure 3).

After analyzing the obtained results, an observation arises as the main contents of diesel engine exhausts are constituted by fraction of $\mathrm{dp}<0.25 \mu \mathrm{m}$ which is probably connected with the manner of sampling. In this study, samples were taken directly from the engine exhaust while an exhaust 

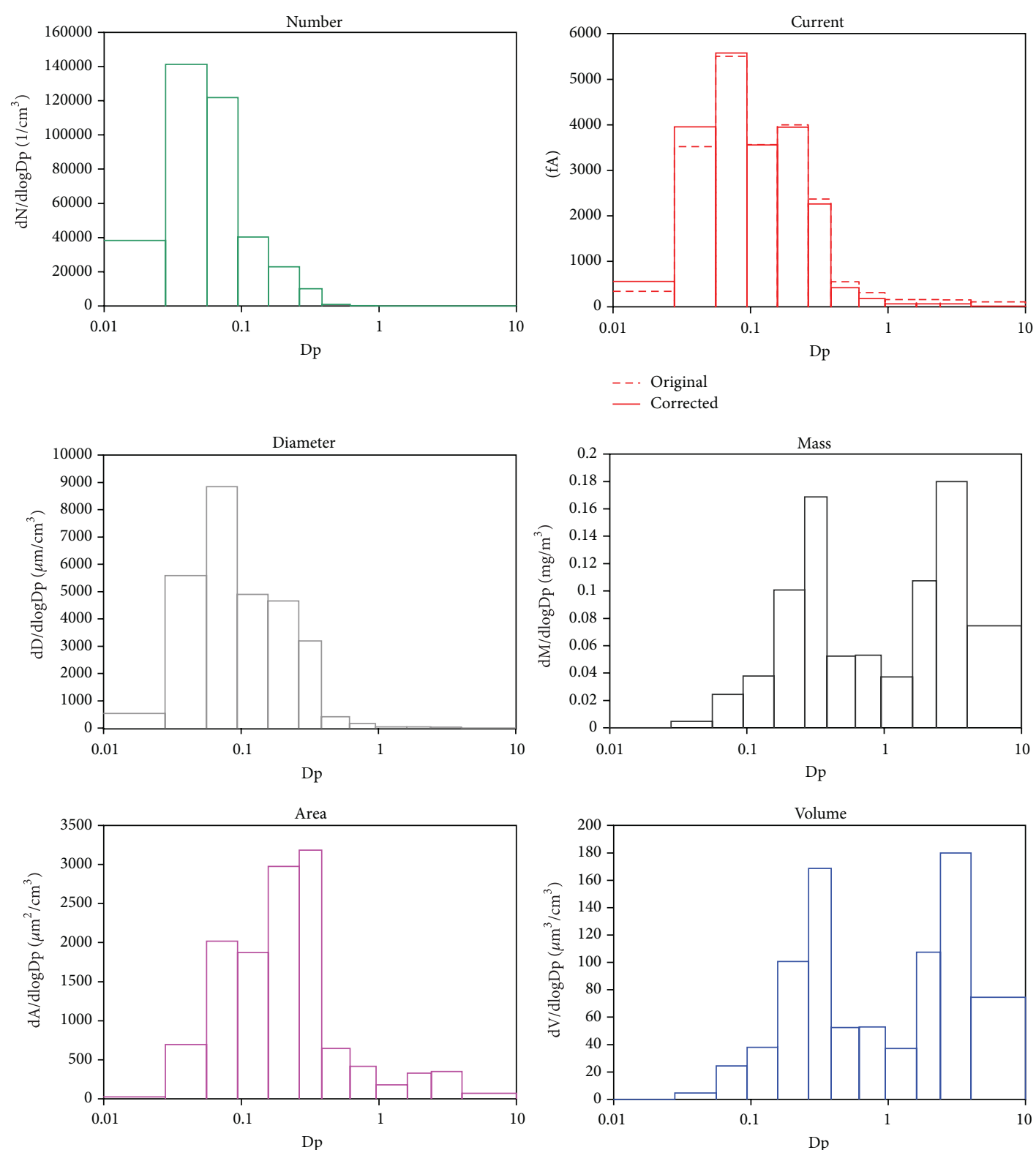

(a)
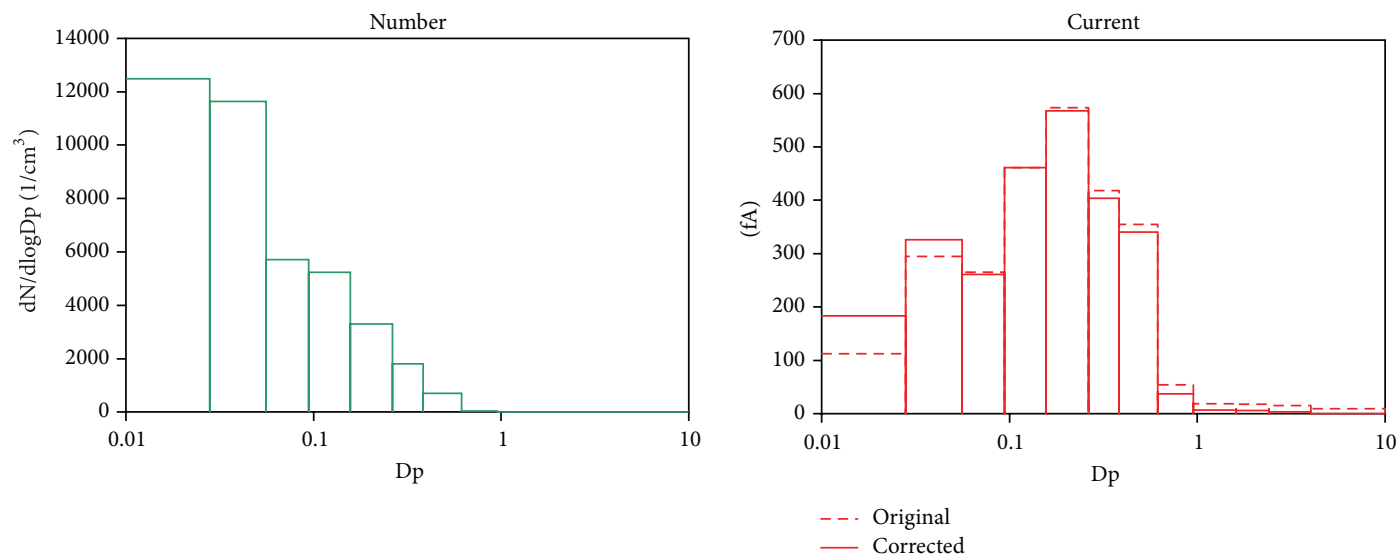

Figure 2: Continued. 

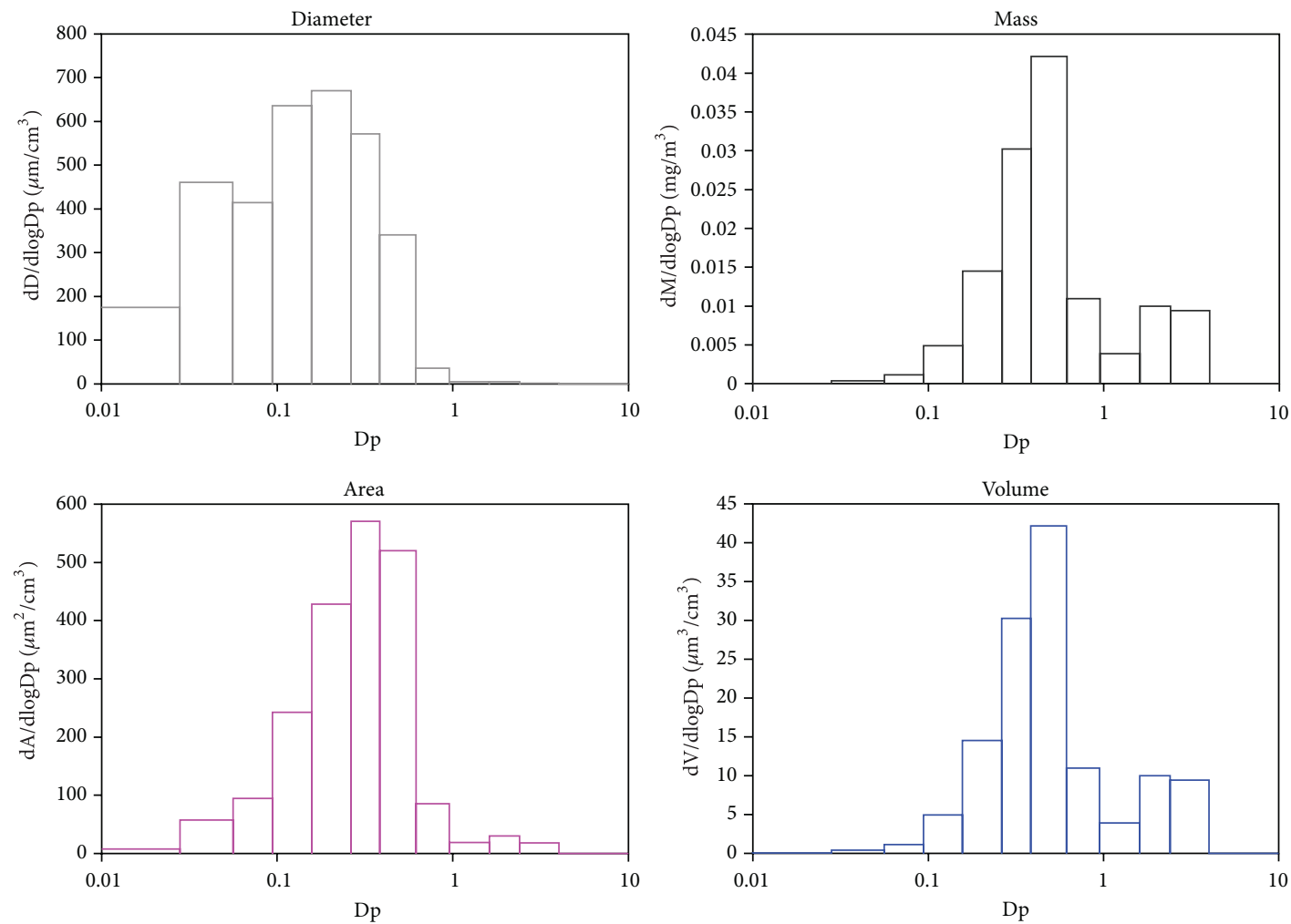

(b)

FIGURE 2: Histograms of particle distribution obtained during one measurement day for on (a) and b40 (b) fuels. Legend: Dp-Particle aerodynamic diameter, $(\mu \mathrm{m})$, current, (fA), number dN/dlogDp, $\left(1 / \mathrm{cm}^{3}\right)$, diameter $\mathrm{dD} / \mathrm{dlogDp},\left(\mu \mathrm{m} / \mathrm{cm}^{3}\right), \operatorname{volume} \mathrm{dV} / \mathrm{dlogDp},\left(\mu \mathrm{m}^{3} / \mathrm{cm}^{3}\right)$, area $\mathrm{dA} / \mathrm{d} \operatorname{logDp},\left(\mu \mathrm{m}^{2} / \mathrm{cm}^{3}\right)$, mass $\mathrm{dM} / \mathrm{d} \log \mathrm{Dp},\left[\mathrm{mg} / \mathrm{m}^{3}\right]$.

gas temperature was high. As the size of particulates grows with the decrease of exhaust gas temperature, for high temperatures $\left(>160^{\circ} \mathrm{C}\right)$ of exhaust gases particles of size lower than $1 \mu \mathrm{m}$ constitute approximately $96 \%$ of the total emission mass while in low temperatures $\left(<110^{\circ} \mathrm{C}\right)$ the amount drops. It is assumed that with a decrease of a temperature to approx. $119-159^{\circ} \mathrm{C}$, a rapid growth of the number of bigger particles occurs $(98 / 83 / \mathrm{EC})$.

3.1. Gravimetric Determination of Mass Concentration of Exhaust Gas Fractions. In order to determine a mass concentration for respective fractions of dust emitted from diesel engine exhaust gases before analyzing a chemical composition of diesel gas particles separated on ELPI collecting plates, filters collecting respective fractions were weighed with a use of an ultrabalance. The results of examination of mass concentration of diesel engine exhaust gas particulates, operated with the use of biofuel mixtures, are presented in Table 2.

The analysis of a distribution of mass concentrations for respective fractions of particles emitted from the exhaust fumes (with a dedicated use of Electrical Low Pressure Impactor (ELPI) for which it was possible to determine fractions of diameter from $10 \mu \mathrm{m}$ to below $0.03 \mu \mathrm{m}$ ) indicates a decrease in mass concentration of particles diameter below $1 \mu \mathrm{m}$ along with the increase of B100 bioester contents in the biofuel mixture (Figure 4).
With application of B40 mixture, the reduction of particles emission of $\mathrm{dp}$ below $1 \mu \mathrm{m}$ totals on average approximately $80 \%$ compared to pure diesel fuel (ON), similar to real-time observation of particle distribution with the use of ELPI for which the obtained average value of reduction of total mass concentration of particles amounts to nearly $70 \%$.

3.2. Particle Fractions of Polycyclic Aromatic Hydrocarbons in diesel Engine Exhaust Gas. A determination of polycyclic aromatic hydrocarbons (PAHs) in individual fractions of diesel exhaust fumes required a collection of adequate mass of material (dust) for an examination. The use of ELPI impactor to examine the chemical composition of respective fractions in the range from $10 \mu \mathrm{m}$ to $0.03 \mu \mathrm{m}$ and a system of 64 fold dilution of the collected fumes enables an idetification of PAHs deposited on separated dust fractions.

Table 3 presents the PAHs identified in respective fractions of diesel engine exhausts fractions with the use of ELPI.

However, an insufficient mass of diesel exhaust particles in particles fractions of diameters from $1.6 \mu \mathrm{m}$ to $10 \mu \mathrm{m}$ and in $0.007 \mu \mathrm{m}$ made the analysis of their chemical composition impossible. In other fractions, the highest volume of PAHs was identified in $\mathrm{ON}$ fumes. While in exhaust fumes of $100 \%$ ON fuel mainly 3- and 4-ring aromatic hydrocarbons occured, in B40 mixture single hydrocarbons with 4 and 5 rings were identified. The identification data of individual 


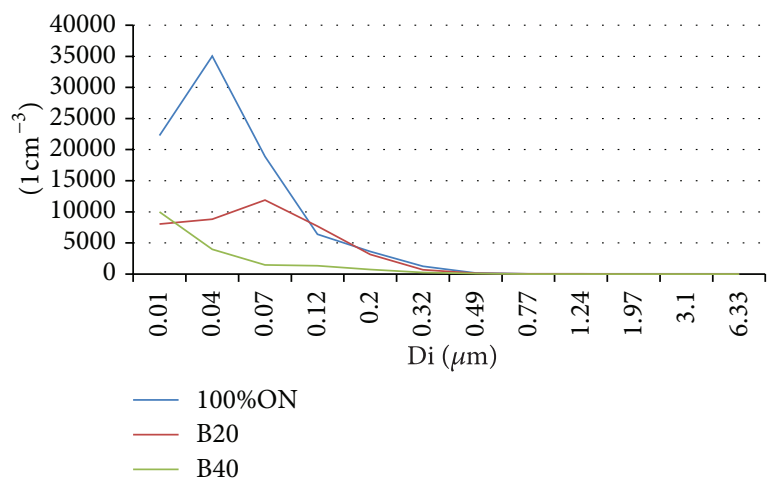

(a)

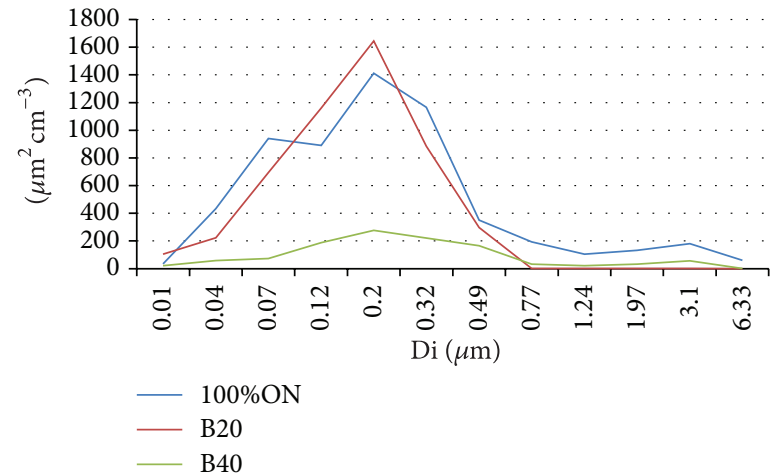

(b)

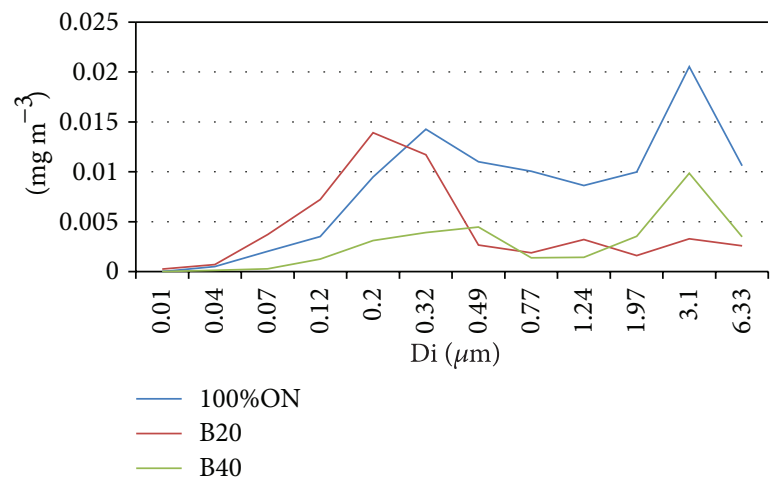

(c)

Figure 3: Mean values of number (a), size (b) and mass concentrations distribution (c) for three biofuel mixtures. Legend: Di geometric mean of a channel (aerodynamic diameter), $[\mu \mathrm{m}]$, number dN/dlogDp, $\left[1 / \mathrm{cm}^{3}\right]$, diameter $\mathrm{dD} / \mathrm{d} \log \mathrm{Dp},\left[\mu \mathrm{m} / \mathrm{cm}^{3}\right], \mathrm{mass} \mathrm{dM} / \mathrm{dlogDp},\left[\mathrm{mg} / \mathrm{m}^{3}\right]$.

TABLE 2: Average mass concentration of diesel engine exhaust gas particulates measured with ELPI.

\begin{tabular}{|c|c|c|c|c|}
\hline \multicolumn{5}{|c|}{$\operatorname{EPLI}(n=3)^{*}$} \\
\hline \multirow{2}{*}{ Storage } & \multirow{2}{*}{$\mathrm{D} 50 \%[\mu \mathrm{m}]$} & Diesel ON & B20 & B40 \\
\hline & & \multicolumn{3}{|c|}{ Mass concentration $\left[\mathrm{mg} \mathrm{m}^{-3}\right]$} \\
\hline Filter no. & 0.007 & 2.716 & 2.267 & 0.043 \\
\hline 1 & 0.03 & 2.449 & 0.623 & 0.341 \\
\hline 2 & 0.06 & 2.512 & 0.115 & 0.545 \\
\hline 3 & 0.108 & 1.991 & 0.174 & 0.352 \\
\hline 4 & 0.17 & 2.137 & 0.190 & 0.372 \\
\hline 5 & 0.26 & 2.070 & 0.369 & 0.301 \\
\hline 6 & 0.40 & 1.838 & 1.166 & 0.492 \\
\hline 7 & 0.65 & 1.898 & 0.574 & 0.552 \\
\hline 8 & 1.0 & 1.936 & 0.610 & 0.498 \\
\hline 9 & 1.6 & 3.543 & 0.650 & 0.501 \\
\hline 10 & 2.5 & 0.218 & 0.680 & 0.541 \\
\hline 11 & 4.4 & 0.207 & 0.721 & 0.503 \\
\hline 12 & 6.8 & - & - & - \\
\hline 13 & 10 & 0.090 & 0.151 & 0.106 \\
\hline \multicolumn{2}{|c|}{ Total mass concentration for fraction $<0.25 \mu \mathrm{m}$} & 13.876 & 3.738 & 1.954 \\
\hline \multicolumn{2}{|c|}{ Total mass concentration } & 23.605 & 8.290 & 5.148 \\
\hline \multicolumn{2}{|l|}{ Min } & 0.090 & 0.115 & 0.043 \\
\hline \multicolumn{2}{|l|}{ Max } & 3.543 & 2.267 & 0.552 \\
\hline
\end{tabular}




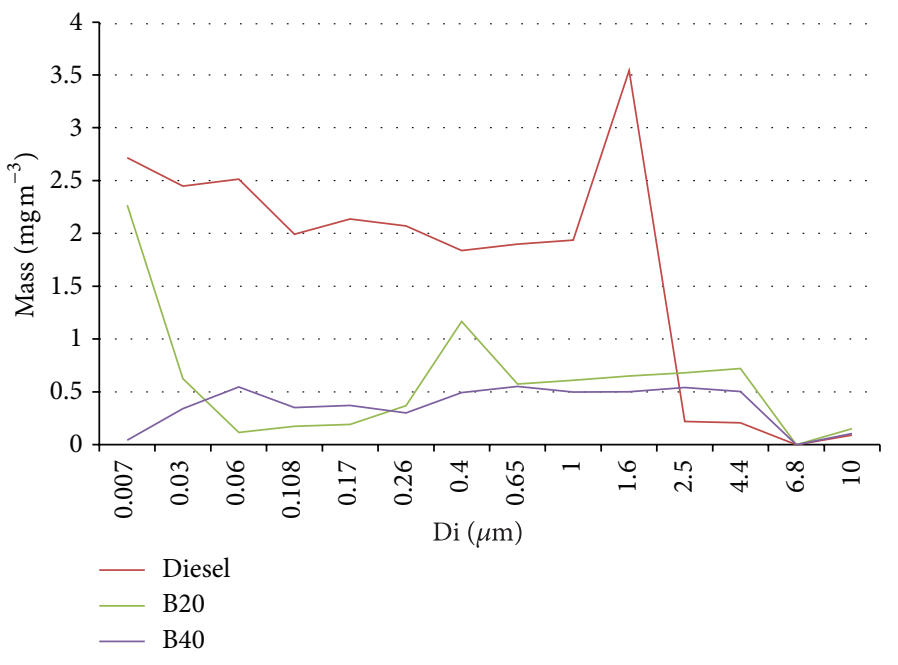

FIGURE 4: Particle mass concentrations of respective fractions of diesel exhaust gas separated with the use of Electric Low Pressure Impactor (ELPI).

TABLE 3: Results of PAHs identification in different particles fraction measured for three types of fuel.

\begin{tabular}{|c|c|c|c|c|}
\hline Storage & $\mathrm{D} 50 \%[\mu \mathrm{m}]$ & Diesel ON & $\begin{array}{c}\text { B20 } \\
\text { Results of PAHs identification }\end{array}$ & B40 \\
\hline 1 & 0.03 & $\begin{array}{c}\text { AC, FL, BaA, CH } \\
\text { BkF, BghiP }\end{array}$ & $\begin{array}{l}\text { FL, BaA } \\
\text { DBA }\end{array}$ & $\begin{array}{l}\mathrm{CH} \\
\mathrm{BkF}\end{array}$ \\
\hline 2 & 0.06 & $\begin{array}{c}\mathrm{AC}, \mathrm{FL} \\
\mathrm{BaA}, \mathrm{CH}, \mathrm{BkF}\end{array}$ & FL, BkF, BghiP & PY, CH, BkF \\
\hline 3 & 0.108 & $\begin{array}{c}\text { AC, FL } \\
\text { BaA, CH } \\
\text { BkF, BghiP }\end{array}$ & $\begin{array}{c}\mathrm{BaA}, \mathrm{CH} \\
\mathrm{BkF}, \mathrm{BaP} \\
\text { BghiP }\end{array}$ & $\begin{array}{l}\mathrm{BaA}, \mathrm{CH} \\
\mathrm{BkF}, \mathrm{BaP}\end{array}$ \\
\hline 4 & 0.17 & $\begin{array}{c}\text { NA, PH } \\
\text { PY, BaA, CH }\end{array}$ & $\begin{array}{c}\mathrm{BaA}, \mathrm{CH} \\
\text { BkF, DBA, BghiP }\end{array}$ & $\begin{array}{c}\mathrm{CH}, \mathrm{BkF} \\
\mathrm{DBA}, \mathrm{BghiP}\end{array}$ \\
\hline 5 & 0.26 & $\begin{array}{c}\text { NA, AC } \\
\mathrm{PH}, \mathrm{AN}, \mathrm{PY}, \mathrm{BaA}\end{array}$ & $\begin{array}{c}\mathrm{CH}, \mathrm{BkF} \\
\mathrm{DBA}, \mathrm{BghiP}\end{array}$ & $\begin{array}{c}\mathrm{CH}, \mathrm{BkF} \\
\text { DBA, BghiP }\end{array}$ \\
\hline 6 & 0.40 & $\begin{array}{c}\text { PY, BaA } \\
\mathrm{CH}, \mathrm{BkF}, \mathrm{BaP}\end{array}$ & $\begin{array}{c}\mathrm{CH}, \mathrm{BkF} \\
\mathrm{DBaA}, \mathrm{BghiP}\end{array}$ & $\begin{array}{l}\text { CH, DBA } \\
\text { BghiP }\end{array}$ \\
\hline 7 & 0.65 & $\begin{array}{c}\text { NA, AC, FL, PH } \\
\text { FLY, PY } \\
\text { BaA, CH }\end{array}$ & $\begin{array}{l}\mathrm{FL}, \mathrm{BaA}, \mathrm{CH}, \mathrm{BkF} \\
\text { DBA, BghiP }\end{array}$ & $\begin{array}{l}\text { BkF } \\
\text { BghiP }\end{array}$ \\
\hline 8 & 1.0 & $\begin{array}{l}\text { NA, AC, FL, PH } \\
\text { FLY, PY, BaA, CH }\end{array}$ & $\begin{array}{c}\text { FL, BaA } \\
\text { CH, BkF, DBA } \\
\text { BghiP }\end{array}$ & Not found \\
\hline 9 & 1.6 & & & \\
\hline 10 & 2.5 & & & \\
\hline 11 & 4.4 & & Not found & \\
\hline 12 & 6.8 & & & \\
\hline 13 & 10 & & & \\
\hline
\end{tabular}


TABLE 4: Results of quantitative PAH analysis in particles fraction of $\mathrm{dp}<0.25 \mu \mathrm{m}$.

\begin{tabular}{|c|c|c|c|c|c|c|c|c|c|c|c|c|c|c|c|}
\hline \multirow{3}{*}{ РAH } & \multicolumn{5}{|c|}{$100 \% \mathrm{ON}$} & \multicolumn{4}{|c|}{ B20 } & \multicolumn{6}{|c|}{ B40 } \\
\hline & Min & Max & Average & SD & RSD [\%] & Min & $\operatorname{Max}$ & Average & $\mathrm{SD}$ & RSD [\%] & Min & $\operatorname{Max}$ & Average & SD & RSD [\%] \\
\hline & \multicolumn{2}{|c|}{$\mathrm{ng} \mathrm{m}^{-3}$} & \multicolumn{2}{|l|}{$\mathrm{ng} \mathrm{m}^{-3}$} & & \multicolumn{2}{|c|}{$\mathrm{ng} \mathrm{m}^{-3}$} & \multicolumn{2}{|l|}{$\mathrm{ng} \mathrm{m}^{-3}$} & \multicolumn{3}{|c|}{$\mathrm{ng} \mathrm{m}^{-3}$} & \multicolumn{2}{|l|}{$\mathrm{ng} \mathrm{m}^{-3}$} & \\
\hline $\mathrm{AC}$ & 1.28 & 1.73 & 1.50 & 0.32 & 21.41 & 2.28 & 3.91 & 2.85 & 0.92 & 32.31 & 5.74 & 6.53 & 6.08 & 0.41 & 6.73 \\
\hline FL & 19.58 & 23.27 & 21.96 & 2.06 & 9.40 & 31.32 & 43.02 & 35.85 & 6.28 & 17.52 & 13.33 & 17.37 & 15.33 & 2.02 & 13.16 \\
\hline $\mathrm{PH}$ & 145.39 & 170.37 & 159.44 & 12.78 & 8.02 & 148.86 & 151.09 & 149.98 & 1.11 & 0.74 & 48.64 & 71.32 & 59.98 & 16.04 & 26.74 \\
\hline AN & 11.83 & 13.21 & 12.56 & 0.70 & 5.55 & 9.33 & 15.55 & 12.96 & 3.23 & 24.97 & 2.67 & 3.82 & 3.25 & 0.58 & 17.79 \\
\hline FLY & 55.30 & 69.70 & 63.44 & 7.38 & 11.64 & 78.59 & 80.26 & 79.62 & 0.90 & 1.13 & 24.11 & 50.71 & 37.94 & 13.33 & 35.13 \\
\hline PY & 274.75 & 349.50 & 304.14 & 39.85 & 13.10 & 147.58 & 196.04 & 168.94 & 24.73 & 14.64 & 96.12 & 115.68 & 103.35 & 10.74 & 10.39 \\
\hline $\mathrm{BaA}$ & 250.35 & 345.27 & 304.97 & 49.05 & 16.08 & 241.76 & 342.02 & 285.01 & 51.52 & 18.08 & 70.32 & 124.62 & 90.33 & 29.83 & 33.03 \\
\hline $\mathrm{CH}$ & 33.77 & 52.30 & 43.07 & 9.27 & 21.52 & 8.51 & 13.82 & 11.52 & 2.72 & 23.65 & 8.32 & 8.78 & 8.55 & 0.33 & 3.84 \\
\hline $\begin{array}{l}\text { Total } \\
\text { PAHs }\end{array}$ & 811.20 & 1002.74 & 910.59 & 95.97 & 10.54 & 678.43 & 809.95 & 746.72 & 65.91 & 8.83 & 291.99 & 430.91 & 340.24 & 78.58 & 23.10 \\
\hline
\end{tabular}

PAHs obtained in separated fractions could be compared with the results published in the work of Corrêa and Arbilla [24], in which the gaseous and solid PAHs phase was determined in diesel fumes $(\mathrm{ON})$, and in B2, B5, and B20 mixtures. The authors collected air samples on Teflon filters and XAD-2 and confirmed the occurrence in the examined exhaust gases of mostly 3 -and 4-ring hydrocarbons, including firstly phenanthrene, fluorene, naphthalene, acenaphthalene, acenaphtylene, and anthracene.

In Table 4 the results of quantitative PAHs analysis in fraction of $\mathrm{dp}<0.25 \mu \mathrm{m}$ are presented. The data indicates that the summary contents of PAHs in ON fumes was on average $910 \mathrm{ng} \mathrm{m}^{-3}$ and decreased with B100 bioester addition to diesel fuel mixture. In B40 exhaust fumes the average summary contents of PAHs was $340 \mathrm{ng} \mathrm{m}^{-3}$ signifying a reduction of PAHs in the fumes by $62 \%$ when compared to the emission of the compounds during diesel fuel combustion.

Similar results were obtained in the work of Lin et al. [10] examining the content of PAHs in exhaust gases of various biodiesel mixtures. The data presented in the publication showed that the summary contents of PAHs in diesel exhaust fumes totaled $7.420 \mathrm{ng} \mathrm{m}^{-3}$, while in the mixture of plant biodiesel $\mathrm{B} 50-3,490 \mathrm{ng} \mathrm{m}^{-3}$ meaning a reduction of PAHs at the level of $52 \%$. In the publication, similarly as in the results obtained in this work, the main contents of PAHs is constituted by low-molecular PAHs, including naphthalene, fluorene, phenanthrene, fluoranthene, and pyrene. At the same time, when comparing the results published in the work of Lin et al [10] with the results in Table 4, a significant differences in the contents of benzo(a)anthracene and benzo $(a)$ pyrene reveals. The contents of benzo $(a)$ anthracene in the examined exhaust gases of various fuel mixtures are fairly significant (resp. 340 and $90 \mathrm{ng} \mathrm{m}^{-3}$ for $100 \% \mathrm{ON}$ and B40) in comparison with other hydrocarbons. However, in the work of Lin et al. [10] the concentration of this compound differs from 6.2 to $3.15 \mathrm{ng} \mathrm{m}^{-3}$ for $\mathrm{ON}$ and B50. The total concentration of benzo(a)pyrene determined by the authors comes to 11 to $4.9 \mathrm{ng} \mathrm{m}^{3}$ for $\mathrm{ON}$ and B50 respectively, but this compound was not identified in samples taken on ELPI (Table 4).

The differences in concentrations and contents of respective PAHs in diesel engine exhaust fumes were influenced by the type and operation of the engine, including the type of injections, power, capacity, applied filters and diesel and biodiesel fuels, duration of engine operation, and duration of measurements. The differences between the results for individual PAHs presented in this work and in the publication [10] may arise from dissimilarities in the type of engine on which the study was conducted, as well as from the type of fuel, in both cases being a subject to comparison. Moreover, since during the launch of a cold engine a substantial part of particulates is formed in the cold exhaust system, the size, the form, and the composition of a particulate matter highly depends on the location within the cylinder-exhaust systematmosphere unit where they are intercepted.

\section{Conclusion}

The main contents in exhaust gases from diesel engine, independently of the type of fuel used in the study, is constituted by the particles fraction of diameters $<0.25 \mu \mathrm{m}$, which was confirmed by the results of actual measurements with the use of ELPI. The presented studies strongly indicates that adding B100 bioester to commonly used diesel fuel (ON) caused a reduction of a total emission of particles and thus a reduction in the amount of toxic substances adsorbed on them. In B40 exhaust fumes, the average summary contents of PAHs came to a reduction of PAHs in the fumes by $62 \%$ when compared to the contents of PAHs in $\mathrm{ON}$ fumes. The analysis of chemical composition of $\mathrm{dp}<0.25 \mu \mathrm{m}$ exhaust gas fraction showed that 3 - and 4-ring aromatic hydrocarbons dominated in exhaust gas of diesel fuel (ON), while in B40 single PAHs with the number of rings of 4 and 5 prevailed. 
These compounds are more carcinogenic PAHs due to their TEQ values [29].

\section{Acknowledgments}

The paper was prepared based on the results obtained within the National Programme: "Improvement of Safety and Working Conditions" (2011-2013). The Central Institute for Labour Protection-National Research Institute is the coordinator of the programme.

\section{References}

[1] M. Matti Maricq, "Chemical characterization of particulate emissions from diesel engines: a review," Journal of Aerosol Science, vol. 38, no. 11, pp. 1079-1118, 2007.

[2] W. B. Bunn, T. W. Hesterberg, P. A. Valberg, T. J. Slavin, G. Hart, and C. A. Lapin, "A reevaluation of the literature regarding the health assessment of diesel engine exhaust," Inhalation Toxicology, vol. 16, no. 14, pp. 889-900, 2004.

[3] A. N. Ozsezen, M. Canakci, A. Turkcan, and C. Sayin, "Performance and combustion characteristics of a DI diesel engine fueled with waste palm oil and canola oil methyl esters," Fuel, vol. 88, no. 4, pp. 629-636, 2009.

[4] F. Aksoy, "The effect of opium poppy oil diesel fuel mixture on engine performance and emissions," International Journal of Environmental Science and Technology, vol. 8, no. 1, pp. 57-62, 2011.

[5] J. Zhang, K. He, X. Shi, and Y. Zhao, "Effect of SME biodiesel blends on PM2.5 emission from a heavy-duty engine," Atmospheric Environment, vol. 43, no. 15, pp. 2442-2448, 2009.

[6] C. Öner and Ş. Altun, "Biodiesel production from inedible animal tallow and an experimental investigation of its use as alternative fuel in a direct injection diesel engine," Applied Energy, vol. 86, no. 10, pp. 2114-2120, 2009.

[7] A. Demirbas, "Progress and recent trends in biodiesel fuels," Energy Conversion and Management, vol. 50, no. 1, pp. 14-34, 2009.

[8] S. A. Basha, K. R. Gopal, and S. Jebaraj, "A review on biodiesel production, combustion, emissions and performance," Renewable and Sustainable Energy Reviews, vol. 13, no. 6-7, pp. 1628-1634, 2009.

[9] Y. C. Sharma, B. Singh, and S. N. Upadhyay, "Advancements in development and characterization of bio diesel: a review," Fuel, vol. 87, pp. 2355-2373, 2008.

[10] Y. C. Lin, W. J. Lee, and H. C. Hou, "PAH emissions and energy efficiency of palm-biodiesel blends fueled on diesel generator," Atmospheric Environment, vol. 40, no. 21, pp. 3930-3940, 2006.

[11] I. M. Atadashi, M. K. Aroua, and A. A. Aziz, "High quality biodiesel and its diesel engine application: a review," Renewable and Sustainable Energy Reviews, vol. 14, no. 7, pp. 1999-2008, 2010.

[12] C. P. Wong, T. L. Chan, and C. W. Leung, "Characterisation of diesel exhaust particle number and size distributions using mini-dilution tunnel and ejector-diluter measurement techniques," Atmospheric Environment, vol. 37, no. 31, pp. 4435-4446, 2003.

[13] L. Int Panis, B. de Geus, G. Vandenbulcke et al., "Exposure to particulate matter in traffic: a comparison of cyclists and car passengers," Atmospheric Environment, vol. 44, no. 19, pp. 2263-2270, 2010.
[14] I. Romieu, F. Castro-Giner, N. Kunzli, and J. Sunyer, "Air pollution, oxidative stress and dietary supplementation: a review," European Respiratory Journal, vol. 31, no. 1, pp. 179-196, 2008.

[15] Y. C. Lin, C. F. Lee, and T. Fang, "Characterization of particle size distribution from diesel engines fueled with palm-biodiesel blends and paraffinic fuel blends," Atmospheric Environment, vol. 42, no. 5, pp. 1133-1143, 2008.

[16] K. Donaldson, L. Tran, L. A. Jimenez et al., "Combustionderived nanoparticles: a review of their toxicology following inhalation exposure," Particle and Fibre Toxicology, vol. 2, article 10, 2005.

[17] C. He, Y. Ge, J. Tan et al., "Comparison of carbonyl compounds emissions from diesel engine fueled with biodiesel and diesel," Atmospheric Environment, vol. 43, no. 24, pp. 3657-3661, 2009.

[18] J. H. Tsai, S. J. Chen, K. L. Huang et al., "PM, carbon, and PAH emissions from a diesel generator fuelled with soy-biodiesel blends," Journal of Hazardous Materials, vol. 179, no. 1-3, pp. 237-243, 2010.

[19] G. Karavalakis, S. Stournas, and E. Bakeas, "Impact of biodiesel blends on fuel consumption and emissions in euro 4 compliant vehicles," Science of the Total Environment, vol. 407, no. 10, pp. 3338-3346, 2009.

[20] C. He, Y. Ge, J. Tan, K. You, X. Han, and J. Wang, "Characteristics of polycyclic aromatic hydrocarbons emissions of diesel engine fueled with biodiesel and diesel," Fuel, vol. 89, no. 8, pp. 2040-2046, 2010.

[21] G. Karavalakis, V. Boutsika, S. Stournas, and E. Bakeas, "Biodiesel emissions profile in modern diesel vehicles. Part 2: Effect of biodiesel origin on carbonyl, $\mathrm{PAH}$, nitro-PAH and oxyPAH emissions," Science of the Total Environment, vol. 409, no. 4, pp. 738-747, 2011.

[22] R. Ballesteros, J. J. Hernández, and L. L. Lyons, "An experimental study of the influence of biofuel origin on particle-associated PAH emissions," Atmospheric Environment, vol. 44, no. 7, pp. 930-938, 2010.

[23] K. J. Swanson, M. C. Madden, and A. J. Ghio, "Biodiesel exhaust: the need for health effects research," Environmental Health Perspectives, vol. 115, no. 4, pp. 496-499, 2007.

[24] S. M. Corrêa and G. Arbilla, "Aromatic hydrocarbons emissions in diesel and biodiesel exhaust," Atmospheric Environment, vol. 40, no. 35, pp. 6821-6826, 2006.

[25] G. A. Westphal, J. Krahl, T. Brüning, E. Hallier, and J. Bünger, "Ether oxygenate additives in gasoline reduce toxicity of exhausts," Toxicology, vol. 268, no. 3, pp. 198-203, 2010.

[26] P. J. Tsai, H. Y. Shieh, W. J. Lee, and S. O. Lai, "Characterization of PAHs in the atmosphere of carbon black manufacturing workplaces," Journal of Hazardous Materials, vol. 91, no. 1-3, pp. 25-42, 2002.

[27] "98/83/EC Council Directive, on the quality of water intended for human consumption," European Commission, Brussels, Belgium, 1998.

[28] "2006/0129 Directive of the European Parliament and of the Council on environmental quality standards in the field of water policy and amending Directive 2000/60/EC," European Commission, Brussels, Belgium, 2006.

[29] PN-Z-04240-5, "Ochrona czystości powietrza-Badania zawartości wielopierścieniowych węglowodorów aromatycznych-Część 5: Oznaczanie antracenu, benzo/a/antracenu, chryzenu, benzo/b/fluorantenu, benzo/k/fluorantenu, benzo/ a/pirenu, dibenzo/ah/antracenu, benzo/ghi/perylenu i indeno/123 cd/pirenu na stanowiskach pracy metoda wysokosprawnej chromatografii cieczowej," 2006. 
[30] J. Baraniecka, K. Pyrzyńska, M. Szewczyńska, M. Pośniak, and E. Dobrzyńska, "Emission of polycyclic aromatic hydrocarbons from selected processes in steelworks," Journal of Hazardous Materials, vol. 183, no. 1-3, pp. 111-115, 2010. 

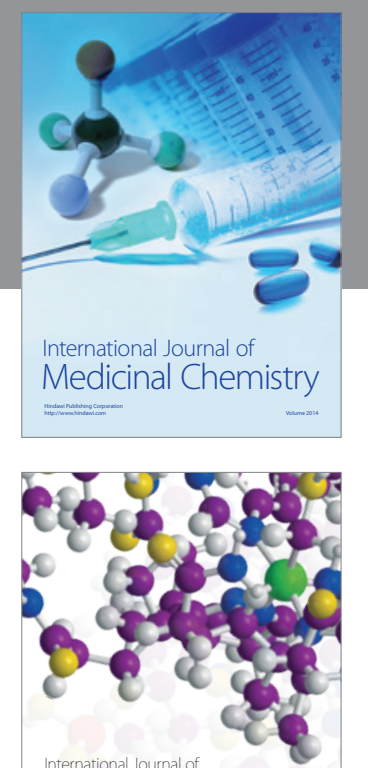

\section{Carbohydrate} Chemistry

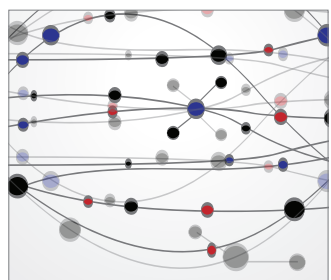

The Scientific World Journal
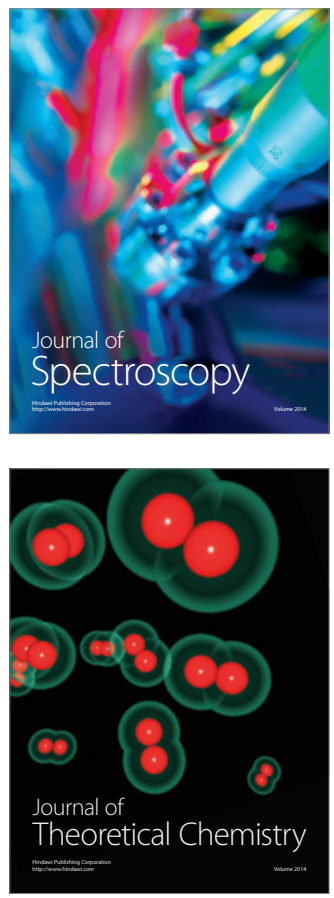
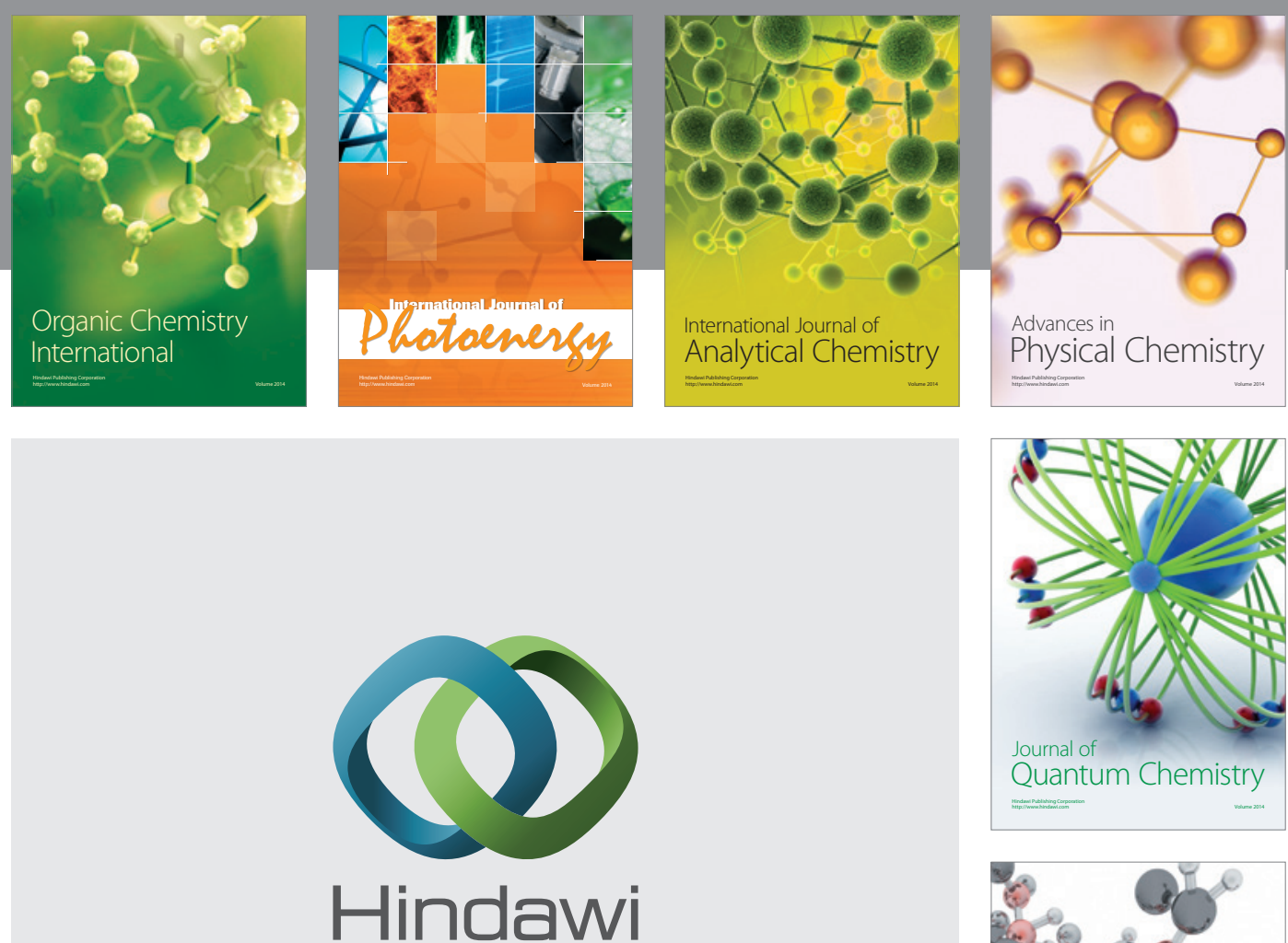

Submit your manuscripts at

http://www.hindawi.com

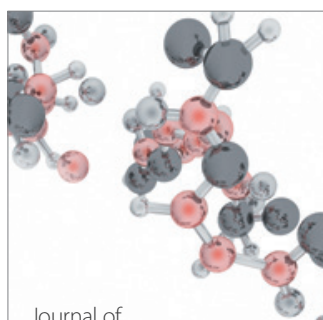

Analytical Methods

in Chemistry

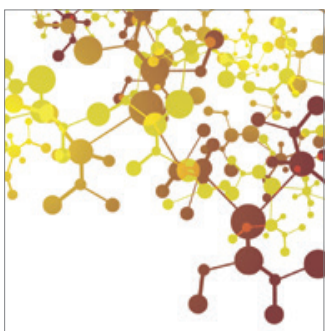

Journal of

Applied Chemistry

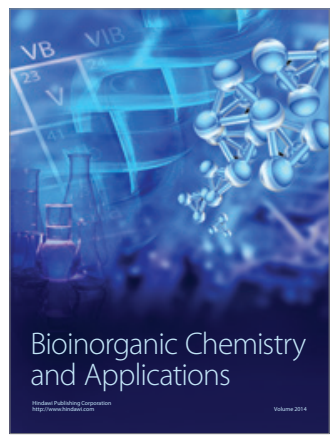

Inorganic Chemistry
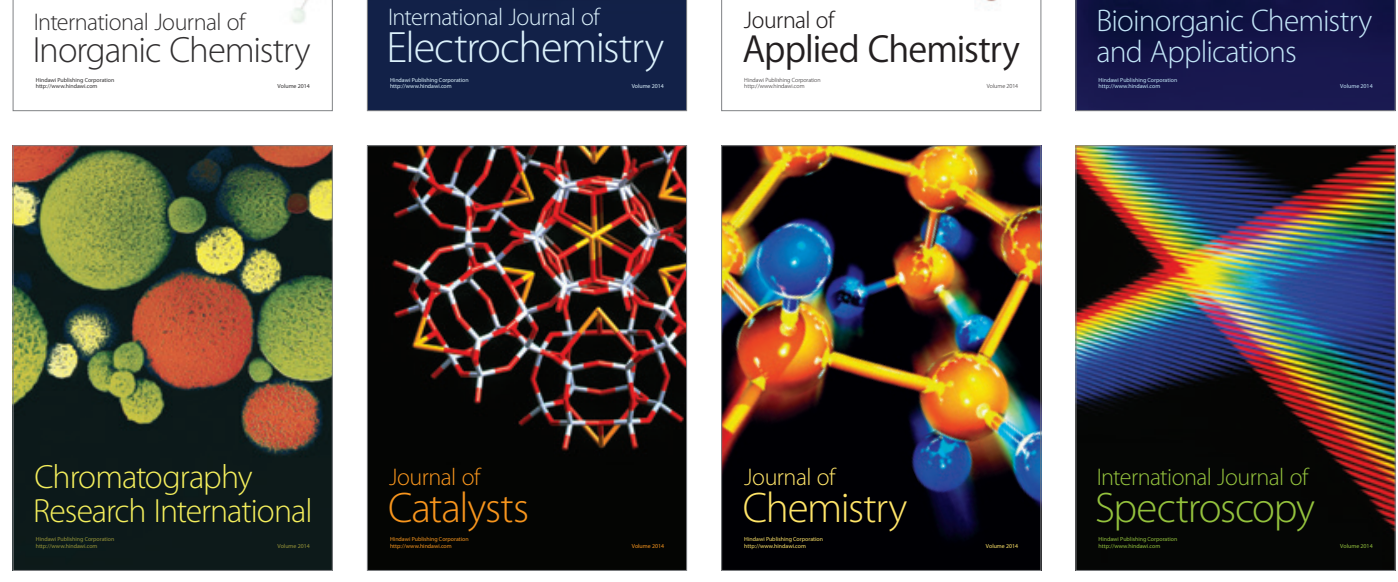